Fish \& Shellfish Immunology

September 2018, Volume 80, Pages 71-79

http://dx.doi.org/10.1016/i.fsi.2018.05.056

http://archimer.ifremer.fr/doc/00442/55337/

(c) 2018 Elsevier Ltd. All rights reserved.

\title{
Temperature modulate disease susceptibility of the Pacific oyster Crassostrea gigas and virulence of the Ostreid herpesvirus type 1
}

\author{
Delisle Lizenn ${ }^{1}$, Petton Bruno ${ }^{2}$, Burguin Jean Francois ${ }^{1}$, Morga Benjamin ${ }^{3}$, Corporeau Charlotte ${ }^{1}$, \\ Pernet Fabrice
}

1 Ifremer,LEMAR UMR 6539, Technopole de Brest-Iroise, 29280, Plouzané, France

${ }^{2}$ Ifremer,LEMAR UMR 6539, Presqu'île du vivier, 29840, Argenton, France

${ }^{3}$ Ifremer,Laboratoire de génétique et Pathologie des Mollusques Marins (LGPMM), Avenue de Mus de Loup, 17390, La Tremblade, France

* Corresponding author : Lizenn Delisle, email address : fabrice.pernet@ifremer.fr

\begin{abstract}
:
Temperature triggers marine diseases by changing host susceptibility and pathogen virulence. Oyster mortalities associated with the Ostreid herpesvirus type 1 (OsHV-1) have occurred seasonally in Europe when the seawater temperature range reaches $16-24^{\circ} \mathrm{C}$. Here we assess how temperature modulates oyster susceptibility to OsHV-1 and pathogen virulence. Oysters were injected with OsHV-1 suspension incubated at $21^{\circ} \mathrm{C}, 26^{\circ} \mathrm{C}$ and $29^{\circ} \mathrm{C}$ and were placed in cohabitation with healthy oysters (recipients) at these three temperatures according to a fractional factorial design. Survival was followed for $14 \mathrm{~d}$ and recipients were sampled for OsHV-1 DNA quantification and viral gene expression. The oysters were all subsequently placed at $21^{\circ} \mathrm{C}$ to evaluate the potential for virus reactivation, before being transferred to oyster farms to evaluate their long-term susceptibility to the disease. Survival of recipients at $29^{\circ} \mathrm{C}$ $(86 \%)$ was higher than at $21^{\circ} \mathrm{C}(52 \%)$ and $26^{\circ} \mathrm{C}(43 \%)$. High temperature $\left(29^{\circ} \mathrm{C}\right)$ decreased the susceptibility of oysters to OsHV-1 without altering virus infectivity and virulence. At $26^{\circ} \mathrm{C}$, the virulence of OsHV-1 was enhanced. Differences in survival persisted when the recipients were all placed at $21^{\circ} \mathrm{C}$, suggesting that OsHV-1 did not reactivate. Additional oyster mortality followed the field transfer, but the overall survival of oysters infected at $29^{\circ} \mathrm{C}$ remained higher.
\end{abstract}

\section{Highlights}

- High temperature $\left(29^{\circ} \mathrm{C}\right)$ decreases the susceptibility of oysters to the virus. There was no alteration of its infectivity and virulence. At $26^{\circ} \mathrm{C}$, the pathogen virulence was enhanced. Disease mitigation measures based on temperature are discussed.

Keywords : Bivalve, Health, Marine disease, Mortality risk, Temperature, Virulence 


\section{Introduction}

The risk of disease outbreaks in the marine environment are governed by interactions between host, parasite, and environmental factors [1]. Of all the environmental factors, seawater temperature plays a decisive role in triggering diseases [2]. Temperature modulates the aptitude of a parasite to colonize its host and the ability of the host to defend itself. For example, mass mortalities of shrimps and sea-stars caused by pathogenic viruses occurred during the warm season [3-5]. Similarly, when abalones were exposed to the pathogenic bacteria Vibrio harveyi, an increase of seawater temperature of one degree during the spawning season altered the hostparasite relation in favor of the pathogen and lead to epidemic disease [6].

In warm-blooded species, fever, which consists of an increase in body temperature, makes it possible to fight against viral and bacterial infections. Although marine animals are mostly ectotherms (cold blooded), the application of high temperature treatments has proven efficient to treat diseases. For instance, shrimps infected with the white spot syndrome virus at $32^{\circ} \mathrm{C}$ showed no mortality, whilst they all died at $25^{\circ} \mathrm{C}[3,7]$.

There is a range of possible influences of high temperature effects on the infectivity of parasites (replication, virulence) and host susceptibility. For instance, high temperature improves shrimp resistance without altering the infectivity of the white spot syndrome virus [3,8]. However, the stability of some shellfish pathogens is altered at high temperature, as reported for the abalone herpesvirus [9].

This study focuses on the effect of high temperatures on the interaction between the Pacific oyster Crassostrea gigas and the Ostreid herpesvirus type 1 (OsHV-1). Indeed, OsHV-1 outbreaks have caused mass mortalities in young oysters along the European coastline since 2008 
and the virus has spread to Australia and New Zealand [10-13]. Seawater temperature defines the start and the end of OsHV-1 epizootics. In France, the optimal seawater temperature range for disease transmission and subsequent mortalities is between $16^{\circ} \mathrm{C}$ and $24^{\circ} \mathrm{C}$ in the field $[14,15]$. In the laboratory, oyster survival of individuals acclimated to temperatures between $13{ }^{\circ} \mathrm{C}$ and $29^{\circ} \mathrm{C}$ exposed to OsHV-1 were much higher when temperatures were exceeded $26^{\circ} \mathrm{C}$ [16]. An Australian study comparing survival of oysters injected with OsHV-1 at $14^{\circ} \mathrm{C}, 18^{\circ} \mathrm{C}, 22^{\circ} \mathrm{C}$ and $26^{\circ} \mathrm{C}$ shows that it was the lowest at $26^{\circ} \mathrm{C}$ [17]. Furthermore, the infectivity of OsHV-1 kept for $54 \mathrm{~h}$ at $25^{\circ} \mathrm{C}$ is lower than at $16^{\circ} \mathrm{C}[18]$.

Although the temperature clearly influences the risk of oyster mortality caused by OsHV-1, it is not known at this time whether the temperature affects the host, by modifying its susceptibility to the virus, the pathogen, by acting on virulence, or both. Also, we do not know if oysters that have survived a high temperature infection are able to transmit the virus to healthy animals and if they remain protected against a second infection. The answer to these questions is crucial to develop OsHV-1 control measures from heat treatment.

Here we tested the effect of three temperatures on disease susceptibility of oysters and virulence of OsHV-1. The control was $21^{\circ} \mathrm{C}$ as this temperature is permissive to OsHV-1 replication and close to the optimal temperature for oyster growth and reproduction [19]. The tested temperatures were $26^{\circ} \mathrm{C}$, a temperature whose effects on the survival of the oyster remains to be clarified, and $29^{\circ} \mathrm{C}$, a temperature at which the survival of oysters exposed to the virus is improved $[16,17]$. These two temperatures are in the thermal range of the oyster since the filtration stops only at $33^{\circ} \mathrm{C}$ and mortality occurs at $38^{\circ} \mathrm{C}$ [19] (Petton com pers).

The first experiment was designed to investigate the effects of high temperatures on OsHV-1 transmission, infection and mortality of oysters. Specific-pathogen-free (SPF) oysters were 
injected with OsHV-1 suspension (pathogen donors) or synthetic seawater (controls) and placed in cohabitation with SPF oysters hereafter called "pathogen recipients" or "control recipients" respectively (Fig. 1). These recipients were previously acclimated or directly dipped (notacclimated) at $21^{\circ} \mathrm{C}, 26^{\circ} \mathrm{C}$ or $29^{\circ} \mathrm{C}$. Their survival was followed for $14 \mathrm{~d}$ and the infectivity of OsHV-1 was evaluated (experiment $1 \mathrm{~A}$ ). Next, the recipients were all placed at $21^{\circ} \mathrm{C}$, and new SPF oysters were added to the tanks in order to evaluate the potential for virus reactivation and transmission (experiment 1B). Finally, recipients were transferred to a farming area where OsHV-1 induced mortalities were occurring to evaluate the long-term susceptibility to the disease (experiment 1C). Concomitantly, a second experiment (experiment 2) evaluated the effect of temperature on the OsHV-1 suspension per se. The viral suspension and synthetic seawater (control) were incubated at $21^{\circ} \mathrm{C}, 26^{\circ} \mathrm{C}$ and $29^{\circ} \mathrm{C}$ prior injection in oysters at $21^{\circ} \mathrm{C}$. Survival of recipients cohabited with injected oysters was followed for $14 \mathrm{~d}$.

\section{Experimental procedures}

\section{Animals and maintenance}

Two cohorts of specific-pathogen-free (SPF) oysters were produced under controlled conditions [20,21]. Briefly, wild oysters were collected in Fouras (Marennes-Oleron, France; 46 00' 43.2' 'N, $1^{\circ} 07^{\prime}$ 02.9' ' W) in August 2015 and were transferred to the Ifremer facilities in Argenton (Brittany, France; 48 $34^{\prime} 30^{\prime \prime} \mathrm{N}, 4^{\circ} 36^{\prime} 18^{\prime \prime} \mathrm{W}$ ) for conditioning. These animals were held in $500 \mathrm{~L}$ flow through tanks with seawater kept at a constant temperature of $17^{\circ} \mathrm{C}$ that was enriched with a phytoplankton mixture. Seawater was UV treated and filtered thought $1 \mu \mathrm{m}$ mesh. Fertilization was performed by stripping the gonads from 100 individuals ( $1 / 3$ males, $2 / 3$ females $)$ on 23 August 2015 (cohort 1) and 23 February 2016 (cohort 2). The fertilization rate was up to 90\%. 
The embryos developed in 1501 tanks at $21^{\circ} \mathrm{C}$ for $48 \mathrm{~h}$, and D-larvae were transferred to flowthrough rearing systems at $25^{\circ} \mathrm{C}$. After 13 days, competent larvae were collected and allowed to settle in downwellers. On 1st October 2015 and 1st April 2016, oysters were transferred to Ifremer facilities in Bouin for nursery where were seawater was UV treated and filtered thought 1 $\mu \mathrm{m}$ mesh (Vendée, France, $46^{\circ} 57^{\prime} 15.5^{\prime \prime} \mathrm{N} 2^{\circ} 02^{\prime} 40.9^{\prime \prime} \mathrm{W}$ ).

The two cohorts of SPF oysters were moved back to Argenton on 28 April 2016 and split into five $500 \mathrm{~L}$ tanks at $21^{\circ} \mathrm{C}$ prior to starting the experiments in open flow systems. At this time, oysters from the first cohort were 8 months old, with a mean weight of $1.48 \mathrm{~g}$. Oysters from the second cohort were $2 \frac{1}{2}$ months old with a mean weight of $0.80 \mathrm{~g}$. The oysters were screened for the herpesvirus by qPCR at all the different production steps it was always undetected [22]. They were fed with a mixture of Chaetoceros muelleri (CCAP 1010/3) and Tisochrysis lutea (CCAP 927/14) (1:1 in dry weight). Food concentration was set at $1500 \mu \mathrm{m}^{3} \cdot \mu \mathrm{l}^{-1}$ of microalgae at the outlet pipe of the tank so that oysters were fed ad libitum [23]. Temperature, salinity, $\mathrm{pH}$ and oxygen were controlled daily with the WTW probes xi3101, cond340, pH3310 and FDO 925, respectively.

Oysters from the first cohort were either injected with a suspension of OsHV-1 (pathogen donors) or synthetic seawater (controls), or they were not injected and used as recipients in both experiments 1 and 2. Oysters from the second cohort served as new recipients in experiment 1B.

\section{Experimental design}

Acclimation of oysters

On 9 May 2016, oysters for injection ( $\mathrm{N}=3000$ individuals) were either left at $21^{\circ} \mathrm{C}$ (control temperature), or gradually increased to $26^{\circ} \mathrm{C}$ and $29^{\circ} \mathrm{C}$ at $2^{\circ} \mathrm{C}$ day ${ }^{-1}$ in three $500 \mathrm{~L}$ tanks (one for 
each temperature, Fig. S1). At the same time, some of the recipient oysters ( $N=3600$ individuals) were transferred to the experimental room, distributed into twenty-five $45 \mathrm{~L}$ tanks and either left at $21^{\circ} \mathrm{C}$ or gradually increased to $26^{\circ} \mathrm{C}$ or $29^{\circ} \mathrm{C}\left(15\right.$ tanks were set at $21^{\circ} \mathrm{C}, 5$ tanks at $26^{\circ} \mathrm{C}$ and 5 tanks at $29^{\circ} \mathrm{C}$, see Table 1). The remaining recipients were left undisturbed in $500 \mathrm{~L}$ tank at $21^{\circ} \mathrm{C}$ and later served as non-acclimated recipients. Acclimation lasted for 11 days up until 19 May.

Each tank was equipped with a thermostat and heating resistor (Biotherm Ecco Hobby and SCHEIGO Titane 300W, Europrix, France) to maintain the seawater at the desired temperature (Fig. S2). Three tanks (one for each temperature) were equipped with a high-frequency temperature data logger (iButton DS1922L) with $0.1^{\circ} \mathrm{C}$ resolution and a final accuracy of \pm $0.3^{\circ} \mathrm{C}$. A light bubbling and a circulation pump (Aquapower 200 superfish 200L/H, Europrix, France) were added in each $45 \mathrm{~L}$ tanks to maintain $>90 \%$ oxygen saturation and seawater homogenization. Seawater salinity was $35 \%$. The oyster filtration rate was measured daily in each tank as reported in [23] (Fig. S3). The water flow was set at $70 \mathrm{~L} \mathrm{~h}^{-1}$ in the $500 \mathrm{~L}$ tanks and $12 \mathrm{~L} \mathrm{~h}^{-1}$ in the $45 \mathrm{~L}$ tank. Throughout this time, there was no oyster mortality.

\section{Infection}

On 19 May 2016, oysters for injection were myorelaxed in $\mathrm{MgCl}_{2}$ solution at their respective acclimation temperature until valve opening [24]. Pathogen donors were injected with $100 \mu 1$ of viral suspension containing $6.9 \times 10^{6}$ copies of OsHV-1 $\mu$ Var in the adductor muscle, while controls were injected with the same volume of sterile synthetic seawater. Donors and controls were further incubated for 5 hours at their respective acclimation temperature.

The viral suspension was obtained from 10 infected oysters. The gills and mantle of these oysters were placed in a sterile $50 \mathrm{ml}$ tube containing 10 volumes of artificial seawater (ASW, $9 \mathrm{~mL} \mathrm{~g}^{-1}$ 

tissue). Tissues were ground on ice using an Ultraturax $(3 \times 5 \mathrm{~s})$ mixer. After centrifugation (1000 g, $\left.5 \mathrm{~min}, 4^{\circ} \mathrm{C}\right)$, the supernatant was transferred to a new tube and diluted in 4 volumes of ASW. The homogenate was filtered under sterile conditions using syringe filters at pore sizes of $5 \mu \mathrm{m}, 2 \mu \mathrm{m}, 0.45 \mu \mathrm{m}$ and $0.22 \mu \mathrm{m}$ (Millipore, Billerica, USA).

Effect of high temperatures on OsHV-1 transmission, infection, and mortality of oysters (experiment 1-part A)

Injected oysters (pathogen donors and controls) were transferred into the $45 \mathrm{~L}$ tanks to cohabit with the recipients acclimated and maintained at $21^{\circ} \mathrm{C}, 26^{\circ} \mathrm{C}$ and $29^{\circ} \mathrm{C}$. Donors were distributed in triplicate tanks while controls were in duplicates for each temperature (Table 1). At the same time, the non-acclimated recipients left at $21^{\circ} \mathrm{C}$ were added to the tanks that contained pathogen donors or controls, and the volume of water was reduced to $30 \mathrm{~L}$ and left stagnant for 12 hours. Dead donors were removed $24 \mathrm{~h}$ post-injection (hpi) and all the donors were removed $72 \mathrm{hpi}$. The biomass of controls and pathogen donors was $230 \mathrm{~g}$ while that of recipients was $350 \mathrm{~g}$ (Fig. 1).

Survival of acclimated and non-acclimated recipients was monitored for 14 days. Thirty living recipients (both acclimated and non-acclimated, 15 individuals for each group) were sampled in each tank at $0,12,24,48$ and $96 \mathrm{~h}$ post-cohabitation (hpc). Whole tissues of 9 recipients out of 15 were removed from the shells, pooled together, flash frozen and stored in liquid nitrogen. Then, oyster tissues were crushed in liquid nitrogen with a MM400 homogenizer (Retsch, Eragny, France) and divided for OsHV-1 DNA and viral gene expression.

\section{Effect of previous temperature treatments on survival of recipients at $21^{\circ} \mathrm{C}$ (experiment 1-part B).}

On 2 June 2016, the temperature of all recipient tanks was set at $21{ }^{\circ} \mathrm{C}$ and new SPF oysters were added. Recipient and new SPF survival was monitored for 11 days up until 13 June. 
Effect of previous temperature treatments on susceptibility of oysters to a second infection in a farming area (experiment 1-part C).

On 13 June 2016, the recipients surviving the experiment 1A and B were transferred into the Bay of Brest at Pointe du Chateau in ( $\left.48^{\circ} 20^{\prime} 06.19^{\prime \prime} \mathrm{N}, 4^{\circ} 19^{\prime} 06.37^{\prime \prime} \mathrm{W}\right)$ where mass mortalities of oysters caused by OsHV-1 were occurring [25], and their survival was followed for 302 days.

\section{Effect of incubation temperature on the OsHV-1 suspension (experiment 2).}

On 19 May 2016, the viral suspension and the synthetic seawater were incubated at $21^{\circ} \mathrm{C}, 26^{\circ} \mathrm{C}$ and $29^{\circ} \mathrm{C}$ for 5 hours before injecting $100 \mu 1$ into the adductor muscle of both pathogen donors and controls kept at $21^{\circ} \mathrm{C}$. Virus suspension remain infectious for $48 \mathrm{~h}$ in seawater at $20^{\circ} \mathrm{C}$ but infectivity decreases after $24 \mathrm{~h}$ [26]. These injected animals remained for $5 \mathrm{~h}$ in six separate tanks (one for each combination of injection type and incubation temperature). Injected oysters (pathogen donors and controls) were transferred to the $45 \mathrm{~L}$ tanks to cohabit with the recipients acclimated at $21^{\circ} \mathrm{C}$. Donors were distributed in triplicate tanks while controls were in duplicates for each temperature (Table 1). The volume of water was reduced to $30 \mathrm{~L}$ and left stagnant for 12 hours. Dead donors were removed 24 hpi and all the donors were removed 72 hpi. The biomass of controls and pathogen donors was $230 \mathrm{~g}$ while that of recipients was $350 \mathrm{~g}$ (Fig. 1). Controls and pathogen donors at $21^{\circ} \mathrm{C}$ were common to experiments 1 and 2 (Table 1).

\section{OsHV-1 DNA quantification}

Level of OsHV-1 DNA was quantified in both control and pathogen recipients, acclimated or non-acclimated, sampled at 0,12, 24, 48 and $96 \mathrm{hpc}$ in experiments $1 \mathrm{~A}$ and 2. These analyses were conducted by the Laboratoire Departemental Veterinaire de l'Herault (Montpellier, France) using oyster powder homogenized in sterile artificial seawater [27]. Total DNA was then 
extracted with a QIAamp tissue mini kit (Qiagen) according to the manufacturer's protocol. The extract was stored at $-20^{\circ} \mathrm{C}$ before detection and quantification according to a real-time PCR protocol based on SYBR Green chemistry [27] with specific primers validated by [28]. The results were expressed as the log of OsHV-1 DNA copies per mg of wet tissue.

Viral gene expression

Viral gene expression was quantified in acclimated pathogen recipients sampled at 24 and $48 \mathrm{hpc}$ in experiments $1 \mathrm{~A}$ and 2.

\section{Total RNA extraction and cDNA synthesis.}

Total RNA was isolated using Extrac-all (Eurobio, Courtaboeuf, France) at a concentration of 1.5 $\mathrm{mL} 30 \mathrm{mg}^{-1}$ powder, and treated with DNAse I (Sigma, $1 \mathrm{U} \mathrm{\mu g}^{-1}$ total RNA). Samples were then treated with DNAse (DNase Max ${ }^{\mathrm{TM}} \mathrm{Kit}$, MO BIO laboratories, Inc) using $\left(1 \mathrm{U}^{-1} \mathrm{~g}^{-1}\right.$ total RNA) to remove genomic DNA. Quality of RNA and quantity were determined using a NanoDrop 2000 (Thermo Scientific). First strand cDNA synthesis was performed using the iScript ${ }^{\mathrm{TM}}$ cDNA Synthesis Kit (BIO-RAD) with 1 1 g of RNA [29]. A no reverse transcription was performed after each DNAse treatment using real time PCR to control for the absence of oyster and virus genomic DNA.

\section{Real time PCRs and relative expression.}

Six viral genes (ORFs 27, 38, 41, 67, 87 and 99) were selected among the 39 ORFs described by [30]. These ORFs encoded for different protein functions and expressed differently during an OsHV-1 replication cycle [30]. 
The real-time PCR assay was performed in triplicate with $5 \mu \mathrm{l}$ cDNA (1/10 dilution) in a total volume of $10 \mu \mathrm{L}$. The concentrations of the reaction components were as follows: $10 \mu \mathrm{M}$ of each primer, $1.5 \mu 1 \mathrm{H} 2 \mathrm{O}, 7.5 \mu 1$ of $\mathrm{iQ}^{\mathrm{TM}}$ SYBR Green Supermix (BIO-RAD). Real time PCR cycling conditions were as follows: activation at $95^{\circ} \mathrm{C}$ for $5 \mathrm{~min}$ followed by 45 cycles of $30 \mathrm{~s}$ at $95^{\circ} \mathrm{C}, 1$ min at $60^{\circ} \mathrm{C}$, and a melting curve program from 95 to $70^{\circ} \mathrm{C}$ by decreasing the temperature by $0.5^{\circ} \mathrm{C}$ every $10 \mathrm{~s}$. Each run included a positive cDNA control (a pool of the $30 \mathrm{cDNA}$ samples of the present experiment analyzed in each amplification plate) and in all cases negative controls (without cDNA) were included to rule out DNA contamination. The elongation factor-1 (EF) from C. gigas was chosen to normalize the viral gene expression. PCR efficiency (E) was determined by drawing standard curves from a serial dilution analysis of the pool of cDNA to ensure that $\mathrm{E}$ ranged from $99 \%$ to $108 \%$ for each primer pair.

The calculation of the relative mRNA levels was based on a comparative $\mathrm{Ct}$ method [31]. No differences between $\mathrm{Ct}$ values were observed for $\mathrm{EF}$ among temperatures and between injection types and times. Therefore, the relative quantification value of the samples was normalized with $\mathrm{EF}$ and relative to the positive control, and was expressed as $2^{-\Delta \Delta \mathrm{Ct}}, \Delta C t=[C t(\operatorname{cDNA}$ sample $)-$ $C t$ (positive cDNA control)] and $\Delta \Delta C t=\Delta C t$ of $c D N A-\Delta C t$ of $E F$.

Standard curves were performed for each primer pair using serial dilutions of total DNA, with PCR efficacy $\left(E=10^{(-1 / \text { slope })}\right)$ being subsequently calculated thanks to these curves [32].

\section{Statistical analysis}

Survival functions were computed according to [33]. Survival time was measured in hours (experiments 1A and 2) or days (experiment 1C) from the onset of each experiment phase. The data were read as the number of dead oysters within each tank at each count. Survival time curves 

of recipients were compared using the Cox model (1972) after adjusting for temperature effect $\left(21^{\circ} \mathrm{C}, 26^{\circ} \mathrm{C}, 29^{\circ} \mathrm{C}\right.$, experiments $1 \mathrm{~A}, 1 \mathrm{C}$ and 2$)$, acclimation (acclimated vs non acclimated, experiment 1A) or injection (OsHV-1 vs SSW, experiments 1C). In experiment 1A, the survival of control recipients was not included in the statistical model because it was $100 \%$. The proportionality of hazards (PH) was checked with Martingale residuals [34]. Because the PH assumption was violated, time dependent covariates representing the interaction of the original covariates and times were added to the model. Time $(\mathrm{t})$ was defined as dichotomous: $\mathrm{t} \leq 120 \mathrm{~h}$ or $\mathrm{t}>120 \mathrm{~h}$. Custom hazard ratios were produced by means of contrasts.

Mixed-design ANOVAs were performed to assess differences in (i) OsHV-1 DNA in pathogen recipients (experiments $1 \mathrm{~A}$ and 2), depending on temperature (3 levels, main plot), acclimation (2 levels, subplot) and time (4 levels, sub-subplot) and (ii) the viral gene expression in acclimated pathogen recipients (experiments $1 \mathrm{~A}$ and 2), depending on temperature (3 levels, main plot) and time (2 levels subplot). The replication unit was the tank in which the temperature and infection treatments were applied. All mutual interactions among factors were tested, and Tukey's HSD was used as a post hoc test. The normality of residuals and homogeneity of variances were graphically checked, and the data were $\log (x+1)$ transformed where necessary. Statistical analyses were performed in SAS 9.4 software (SAS institute).

\section{Results}

Effect of high temperatures on OsHV-1 transmission, infection, and survival of oysters (experiment 1A) 
245 The oysters injected with OsHV-1 suspension (pathogen donors) showed significant mortalities $24648 \mathrm{hpi}$ at the three tested temperatures (Fig. S1). Their final survival at $72 \mathrm{hpi}$ was ranked as $29^{\circ} \mathrm{C}$ $247 \quad(72 \pm 2.1 \%)>26^{\circ} \mathrm{C}(62 \pm 2.1 \%)>21^{\circ} \mathrm{C}(46 \pm 2.6 \%)$.

248 The survival of control recipients (oysters living in cohabitation with SSW injected oysters) was $249100 \pm 0 \%$ irrespective of temperature and acclimation treatments (data not shown), but low 250 levels of OsHV-1 DNA were occasionally detected in these animals $\left(<10^{3} \mathrm{cp} \mathrm{mg}^{-1}\right.$ wet tissue, 251 Table S1). Although control recipients were no longer considered SPF, absence of mortality suggest that they were healthy, and only the pathogen recipients were considered hereafter.

At the end of the cohabitation trial, the survival of pathogen recipients acclimated at $29^{\circ} \mathrm{C}$ was higher $(85.7 \pm 2.0 \%)$ than at $21^{\circ} \mathrm{C}$ and $26^{\circ} \mathrm{C}$, where survival rates were $52.4 \pm 3.1 \%$ and $43.9 \pm$ $3.1 \%$ respectively (Fig. 2A). Survival of non-acclimated pathogen recipients was $5-9 \%$ lower than that of their acclimated counterparts irrespective of temperature. Mortality started $72 \mathrm{~h}$ post257 cohabitation (hpc) at $26^{\circ} \mathrm{C}$ and $120 \mathrm{hpc}$ at $21^{\circ} \mathrm{C}$ (Fig. 2A). Overall, mortality risk was lowest at $29^{\circ} \mathrm{C}($ Table S2).

At the onset of the experiment, OsHV-1 DNA was not detected in SPF oysters. Between 0-24 hpc, the level of OsHV-1 DNA in pathogen recipients increased above $10^{4} \mathrm{cp}_{\mathrm{mg}} \mathrm{m}^{-1}$ irrespective of 261 temperatures, but rates of increase were the highest at $26^{\circ} \mathrm{C}$ and $29^{\circ} \mathrm{C}$ (Fig. $2 \mathrm{~B}$, Table S3). 262 Between 24-48 hpc, the level of OsHV-1 DNA continued to increase at $21^{\circ} \mathrm{C}$, remained high at $26326^{\circ} \mathrm{C}$, and initiated a decrease at $29^{\circ} \mathrm{C}$. Therefore, at $48 \mathrm{hpc}$, the level of OsHV-1 DNA ranked as $26426^{\circ} \mathrm{C}=21^{\circ} \mathrm{C}>29^{\circ} \mathrm{C}$. Finally, between $48-96 \mathrm{hpc}$, OsHV-1 DNA decreased at $26^{\circ} \mathrm{C}$ and $29^{\circ} \mathrm{C}$ while it remained stable at $21^{\circ} \mathrm{C}$. Therefore, at $96 \mathrm{hpc}$, OsHV-1 DNA ranked as $21^{\circ} \mathrm{C}>26^{\circ} \mathrm{C}=$ $29^{\circ} \mathrm{C}$. Interestingly, maximum values of OsHV-1 DNA were similar among temperatures 
267

268

$\left(1.9 \times 10^{6} \mathrm{cp} \cdot \mathrm{mg}^{-1}\right.$ at $21^{\circ} \mathrm{C} 48 \mathrm{hpc} ; 3.4 \times 10^{6} \mathrm{cp} \cdot \mathrm{mg}^{1}$ at $26^{\circ} \mathrm{C} 24 \mathrm{hpc}$ and at $29^{\circ} \mathrm{C}, 4.0 \times 10^{5} \mathrm{cp} \cdot \mathrm{mg}^{-1} 24$ hpc) but these maximum values were observed for longer at $26^{\circ} \mathrm{C}$ and $21^{\circ} \mathrm{C}$ than at $29^{\circ} \mathrm{C}$.

The six viral Open Reading Frames (ORFs) selected in our study were expressed in pathogen recipients at the three tested temperatures. Three of them were modulated by temperature (ORFs 27, 38 and 87). Gene expression levels were highest at $26^{\circ} \mathrm{C}$, except ORF 87 at $48 \mathrm{hpc}$, which exhibited the highest values at $21^{\circ} \mathrm{C}$. At $29^{\circ} \mathrm{C}$, viral gene expressions of these three ORFs were lower than at $26^{\circ} \mathrm{C}$ and $21^{\circ} \mathrm{C}$. Viral gene expression of the other ORFs (41,67 and 99) increased between 24 and 48 hpc (Fig. 2C and D).

Effect of previous temperature treatments on recipient survival at $21^{\circ} \mathrm{C}$ (experiment $1 \mathrm{~B}$ ).

The survival of both control and pathogen recipients placed at $21^{\circ} \mathrm{C}$ for 11 days was $100 \pm 0 \%$ irrespective of previous temperature treatments (data not shown). Moreover, the new SPF oysters placed in cohabitation with them showed no mortality.

Effect of previous temperature treatments on oyster susceptibility to a second infection in a farming area (experiment $1 C)$.

Both pathogen and controls recipients transferred to a farming area where OsHV-1 occurred showed high mortalities. However, the survival of pathogen recipients was higher $(75.9 \pm 5.3 \%)$ than that of control recipients $(44.9 \pm 9.9 \%$, Fig. 3, Table S4). There was no effect of previous temperature treatments on the survival of control recipients. In contrast, the survival of the pathogen recipients infected at $29^{\circ} \mathrm{C}$ was lower $(67.9 \pm 10.8 \%)$ than those infected at $21^{\circ} \mathrm{C}$ and $26^{\circ} \mathrm{C}$, where survival was $79.3 \pm 3.7 \%$ and $80.6 \pm 5.5 \%$ respectively. Throughout the whole experiment 1 , the survival of the pathogen recipients previously exposed to donors at $29^{\circ} \mathrm{C}$ 
remained higher $(56.6 \%)$ than at $21^{\circ} \mathrm{C}$ and $26^{\circ} \mathrm{C}$, where survival was $41.9 \%$ and $32.0 \%$ respectively.

Effect of incubation temperature on the OsHV-1 suspension (experiment 2).

291 As observed in experiment 1, the survival of control recipients was $100 \pm 0 \%$ but low levels of

292 OsHV-1 DNA were occasionally detected $\left(<10^{2} \mathrm{cp} \mathrm{mg}{ }^{-1}\right.$ wet tissue, Table S1). However, given 293 the absence of mortality and temperature effect on control recipients, only the pathogen recipients 294 were considered hereafter.

295 Pathogen recipients showed significant mortalities after $72 \mathrm{hpc}$ (Fig. 4A, Table S5). At the end of experiment 2, the survival of pathogen recipients ranked as a function of incubation temperature of the viral suspension: $26^{\circ} \mathrm{C}(46 \pm 3 \%)<21^{\circ} \mathrm{C}=29^{\circ} \mathrm{C}(52 \pm 2 \%)$. The level of OsHV-1 DNA and viral gene expression in pathogen recipients increased during the experiment but were not influenced by the incubation temperature of the viral suspension (Fig. 4B and C).

300

301

\section{Discussion}

The major result of this study is that the survival of recipient oysters exposed to the virus at $29^{\circ} \mathrm{C}$ (85.7\% survival) was markedly higher than at $21^{\circ} \mathrm{C}$ and $26^{\circ} \mathrm{C}(52.4 \%$ and $43.9 \%$ respectively), reflecting changes in host susceptibility and/or virus virulence. This concurs with a previous study where recipients cohabited with field-infected donors [16]. These differences in survival persisted when the pathogen recipients were all placed at $21^{\circ} \mathrm{C}$, the optimal temperature for OsHV-1 replication, and when they were re-exposed to OsHV-1 in the field. This result opens new perspectives for mitigation measures using high temperature. 
The differences in survival between recipients exposed to OsHV-1 at $21^{\circ} \mathrm{C}$ and $29^{\circ} \mathrm{C}$ coincided with differences in viral replication in the host. Although levels of OsHV-1 DNA increased from undetectable amounts to values higher than $10^{4} \mathrm{DNA} \mathrm{cp} \mathrm{mg}^{-1}$ (the threshold at which mortality generally occurs) for both temperatures during the first $24 \mathrm{hpc}$, it then decreased markedly in recipients at $29^{\circ} \mathrm{C}$ whereas it continued to increase at $21^{\circ} \mathrm{C}$. A similar pattern was observed in SPF oysters having cohabited with field infected donors at these two temperatures [16]. In our study, the expression of three viral genes (ORF 27, 38 and 87) involved in regulation of a ring finger motif, DNA repairing and apoptosis inhibition [30] were lower in recipients at $29^{\circ} \mathrm{C}$ than at $21^{\circ} \mathrm{C}$. High temperature may reduce the expression of some viral genes that could be essential to the development of the disease and viral cycle. Also, equally high expression levels of ORF 41,67 and 99 at $21^{\circ} \mathrm{C}$ and $29^{\circ} \mathrm{C}$ suggest the induction of the OsHV-1 lytic cycle irrespective of temperature [35].

Survival of pathogen donors at $29^{\circ} \mathrm{C}$ was higher than at $21^{\circ} \mathrm{C}$, as observed in pathogen recipients. This suggests that high temperature $\left(29^{\circ} \mathrm{C}\right)$ decreased the susceptibility of oysters to OsHV-1. This, however, raises the possibility that viral shedding of pathogen donors at $29^{\circ} \mathrm{C}$ was lower than that at $21^{\circ} \mathrm{C}$, which could have contributed to the increased survival of the pathogen recipients at $29^{\circ} \mathrm{C}$.

We also found that these temperatures $\left(21^{\circ} \mathrm{C}\right.$ and $\left.29^{\circ} \mathrm{C}\right)$ had no effect on the virus suspension per se. Indeed, the survival, level of OsHV-1 DNA and virus gene expression of recipients at $21^{\circ} \mathrm{C}$ having cohabited with donors injected with viral suspension incubated were all similar at $21^{\circ} \mathrm{C}$ or $29^{\circ} \mathrm{C}$. Therefore, high temperature $\left(29^{\circ} \mathrm{C}\right)$ had no effect on the infectivity (a measure of the ability of a disease agent to establish itself in the host) or the virulence (a measure of the severity of a disease) of OsHV-1. 
331 Therefore, high temperature $\left(29^{\circ} \mathrm{C}\right)$ decreased the susceptibility of oysters to OsHV-1 without

332 altering virus infectivity and virulence; however, the underlying mechanism remains unknown.

333 Temperature impacts all aspects of ectotherm physiology, including their immunity [36]. For

334 instance, the antiviral response of oysters is stimulated at $22^{\circ} \mathrm{C}$ compared to $12^{\circ} \mathrm{C}$ [37]. High

335 temperatures $\left(32^{\circ} \mathrm{C}\right)$ induce overexpression of heat shock proteins 70 involved in the repression

336 of white spot syndrome virus replication in shrimps [38].

337 At $26^{\circ} \mathrm{C}$, the mortality of pathogen recipients started earlier than at $21^{\circ} \mathrm{C}$ and $29^{\circ} \mathrm{C}$, survival was 338 lowest, levels of OsHV-1 DNA were highest (between 12-48 hpc) and the expression of three 339 viral genes was enhanced. Furthermore, the survival of pathogen recipients having cohabited with 340 donors injected with viral suspension incubated at $26^{\circ} \mathrm{C}$ was lowest, but levels of OsHV-1 DNA 341 and viral gene expression were similar among temperature treatments. Therefore, it appears that 342 the virulence of OsHV-1 was enhanced at $26^{\circ} \mathrm{C}$, although an increase in susceptibility of the host 343 cannot be ruled out.

344 In our study, the survival of pathogen recipients at $26^{\circ} \mathrm{C}$ is the lowest as reported by [17].

345 However, in a previous study, survival of oysters exposed to OsHV-1 at $21^{\circ} \mathrm{C}$ was lower than at $34626^{\circ} \mathrm{C}$ [16]. Discrepancies may reflect different methods of infection among studies. Here, the 347 donors were injected with a viral suspension, whereas in [16] they were naturally infected by a 348 short exposure to field conditions where OsHV-1 induced mortalities of oysters were occurring. 349 Therefore, their study probably encompasses other microorganisms naturally encountered in the 350 marine environment, including populations of pathogenic vibrios that influence oyster survival $351 \quad[22,39]$. 
When temperature of pathogen recipients decreases from $29^{\circ} \mathrm{C}$ to $21^{\circ} \mathrm{C}$, a temperature permissive for OsHV-1 replication, there was neither additional mortality nor disease transmission to the new SPF oysters. Although high temperature increases elimination of several viruses in oysters [40], herpesviruses are generally incurable and complete elimination from the host is unlikely [41]. Our results suggest that OsHV-1 did not reactivate at $21^{\circ} \mathrm{C}$, or at least not sufficiently to induce mortality. However, OsHV-1 can persist in oysters for several months at low temperatures $\left(<13^{\circ} \mathrm{C}\right)$ and can reactivate and kill the host after a thermal elevation to $21^{\circ} \mathrm{C}$ [42].

Recipients showed additional mortalities following the second exposure to OsHV-1 in the field. The survival of pathogen recipients previously infected at $29^{\circ} \mathrm{C}$ was lower than those infected at $21^{\circ} \mathrm{C}$ and $26^{\circ} \mathrm{C}$, likely reflecting the persistence of a greater number of susceptible hosts at $29^{\circ} \mathrm{C}$.

Throughout the whole experiment, the survival of recipients exposed to pathogen donors at $29^{\circ} \mathrm{C}$ was on average $20 \%$ higher than at $21^{\circ} \mathrm{C}$ and $26^{\circ} \mathrm{C}$. Oysters first infected at $29^{\circ} \mathrm{C}$ seemed less susceptible to the virus than those first infected at $21^{\circ} \mathrm{C}$ and $26^{\circ} \mathrm{C}$. For the second infection, the oysters were $1 \frac{1}{2}$ month older and therefore potentially less susceptible to the pathogen [43]. Also, the first exposure to OsHV-1 may have lowered the susceptibility of oysters to a second infection. A non-lethal exposure to a pathogen can enhance invertebrate immunity by immune priming $[44,45]$. Immune priming against OsHV-1 has already been reported for oysters injected with a synthetic viral analogue [46].

Oysters exposed to the virus at $29^{\circ} \mathrm{C}$ were less susceptible to OsHV-1 than at $21^{\circ} \mathrm{C}$ and $26^{\circ} \mathrm{C}$ over the long term, thus opening new perspectives for mitigation measures. Hyperthermia was already suggested as preventive method in shrimp farming to minimize the risk of a viral outbreak [47]. Regarding the potential of high temperature treatment to mitigate disease risk in 
oyster farms, several questions need to be answered. What is the sanitary status of the oysters exposed to OsHV-1 at high temperature (OsHV-1-free or asymptomatic carrier)? What is the optimal treatment duration and temperature to optimize survival and minimize energy costs? How is it possible to practically implement a high temperature treatment on a production farm? Finally, what are the economic efficiency (i.e. the cost of disease control measures compared to ensuing benefits) and acceptability (the willingness of organizations to put into action disease control measures) of high temperature treatment?

\section{Acknowledgements}

We thank the Ifremer staff involved in oyster and algae production at Argenton and Bouin. We are grateful to Mathias Hubert for helping with the experimental set-up and to Melaine Gourault, Valérian Le Roy, Margaux Mathieu-Resuge, Isabelle Quéau and Claudie Quéré for their help with sampling. We also thank Maelenn Le Roy for helping with the RNA analyses, Amelie Segarra for discussions, and Amelia Curd for her help with English editing. This work was supported by the EU funded project VIVALDI (H2020 program, $\left.\mathrm{n}^{\circ} 678589\right)$ and the TEMPO project funded by the French Ministry of Environment, Energy and Sea (Convention DPMA 2016 16/1212569).

\section{References}

[1] C.A. Burge, C. Mark Eakin, C.S. Friedman, B. Froelich, P.K. Hershberger, E.E. Hofmann, L.E. Petes, K.C. Prager, E. Weil, B.L. Willis, S.E. Ford, C.D. Harvell, Climate Change Influences on Marine Infectious Diseases: Implications for Management and Society, Ann. Rev. Mar. Sci. 6 (2014) 249-277. doi:10.1146/annurev-marine-010213-135029.

[2] C. Harvell, C. Mitchell, J. Ward, S. Altizer, A.P. Dobson, R.S. Ostfeld, M.D. Samuel, 
Climate warming and disease risks for terrestrial and marine biota, Science. 296 (2002) 2158-2163. doi:10.1126/science.1063699.

[3] O.M. Vidal, C.B. Granja, F. Aranguren, J.A. Brock, M. Salazar, A profound effect of hyperthermia on survival of Litopenaeus vannamei juveniles infected with white spot syndrome virus, J. World Aquac. Soc. 32 (2001) 364-372. doi:10.1111/j.17497345.2001.tb00462.x.

[4] A. Staehli, R. Schaerer, K. Hoelzle, G. Ribi, Temperature induced disease in the starfish Astropecten jonstoni, Mar. Biodivers. Rec. 2 (2009) 10-14. doi:10.1017/S1755267209000633.

[5] W.T. Kohl, T.I. McClure, B.G. Miner, Decreased temperature facilitates short-term sea star wasting disease survival in the keystone intertidal sea star Pisaster ochraceus, PLoS One. 11 (2016) 1-9. doi:10.1371/journal.pone.0153670.

[6] M.A. Travers, O. Basuyaux, N. Le Goïc, S. Huchette, J.L. Nicolas, M. Koken, C. Paillard, Influence of temperature and spawning effort on Haliotis tuberculata mortalities caused by Vibrio harveyi: An example of emerging vibriosis linked to global warming, Glob. Chang. Biol. 15 (2009) 1365-1376. doi:10.1111/j.1365-2486.2008.01764.x.

[7] C.B. Granja, L.F. Aranguren, O.M. Vidal, L. Aragon, M. Salazar, Does hyperthermia increase apoptosis in white spot syndrome virus (WSSV) infected Litopenaeus vannamei?, Dis. Aquat. Organ. 54 (2003) 73-78. doi:10.3354/dao054073.

[8] C.B. Granja, O.M. Vidal, G. Parra, M. Salazar, Hyperthermia reduces viral load of white spot syndrome virus in Penaeus vannamei, Dis. Aquat. Organ. 68 (2006) 175-180. doi:10.3354/dao068175. 
418 [9] S. Corbeil, L.M. Williams, J. Bergfeld, M.S.J. Crane, Abalone herpes virus stability in sea

419

420

421

422

423

424

425

426

427

428

429

430

431

432

433

434

435

436

437

438

439 water and susceptibility to chemical disinfectants, Aquaculture. 326-329 (2012) 20-26. doi:10.1016/j.aquaculture.2011.11.031.

[10] V. Barbosa Solomieu, T. Renault, M.A. Travers, Mass mortality in bivalves and the intricate case of the Pacific oyster, Crassostrea gigas, J. Invertebr. Pathol. 131 (2015) 210. doi:10.1016/j.jip.2015.07.011.

[11] EFSA, Scientific opinion on the increased mortality events in Pacific oysters, Eur. Food Saf. Auth. J. 8 (2010) 1-60. doi:10.2903/j.efsa.2010.1894.

[12] F. Pernet, C. Lupo, C. Bacher, R.J. Whittington, Infectious diseases in oyster aquaculture require a new integrated approach, Philos. Trans. R. Soc. B Biol. Sci. 371 (2016) 20150213. doi:10.1098/rstb.2015.0213.

[13] F.J. Jenkins C, Hick P, Gabor M, Spiers Z, Fell SA, Gu X, Read A, Go J, Dove M, O'Connor W, Kirkland PD, Identification and characterisation of an ostreid herpesvirus-1 microvariant (OsHV-1 $\mu$-var) in Crassostrea gigas (Pacific oysters) in Australia., Dis. Aquat. Organ. 105 (2013) 109-126. doi:doi.org/10.3354/dao02623.

[14] F. Pernet, J. Barret, P. Le Gall, C. Corporeau, L. Dégremont, F. Lagarde, J.F. Pépin, N. Keck, Mass mortalities of Pacific oysters Crassostrea gigas reflect infectious diseases and vary with farming practices in the Mediterranean Thau lagoon, France, Aquac. Environ. Interact. 2 (2012) 215-237. doi:10.3354/aei00041.

[15] T. Renault, L. Bouquet, J. Maurice, C. Lupo, Ostreid Herpesvirus 1 Infection among Pacific Oyster (Crassostrea gigas) Spat : Relevance of Water Temperature to Virus Replication and Circulation Prior to the Onset of Mortality, Appl. Environ. Microbiol.80 
440

441

442

443

444

445

446

447

448

449

450

451

452

453

454

455

456

457

458

459

460

461

(2014) 5419-5426. doi:10.1128/AEM.00484-14.

[16] B. Petton, F. Pernet, R. Robert, P. Boudry, Temperature influence on pathogen transmission and subsequent mortalities in juvenile pacific oysters Crassostrea gigas, Aquac. Environ. Interact. 3 (2013) 257-273. doi:10.3354/aei00070.

[17] M. de Kantzow, P. Hick, J. Becker, R. Whittington, Effect of water temperature on mortality of Pacific oysters Crassostrea gigas associated with microvariant ostreid herpesvirus 1 (OsHV-1 $\mu$ Var), Aquac. Environ. Interact. 8 (2016) 419-428. doi:10.3354/aei00186.

[18] C. Martenot, L. Denechère, P. Hubert, L. Metayer, E. Oden, S. Trancart, E. Travaillé, M. Houssin, Virulence of Ostreid herpesvirus $1 \mu \mathrm{Var}$ in sea water at $16^{\circ} \mathrm{C}$ and $25^{\circ} \mathrm{C}$, Aquaculture. 439 (2015) 1-6. doi:10.1016/j.aquaculture.2015.01.012.

[19] S. Bougrier, P. Geairon, J.M. Deslous-Paoli, C. Bather, G. Jonquikres, Allometric relationships and effects of temperature on clearance and oxygen consumption rates of Crassostrea gigas (Thunberg), Aquaculture. 134 (1995) 143-154. doi:10.1016/00448486(95)00036-2.

[20] B. Petton, P. Boudry, M. Alunno-Bruscia, F. Pernet, Factors influencing disease-induced mortality of Pacific oysters Crassostrea gigas, Aquac. Environ. Interact. 6 (2015) 205222. doi:10.3354/aei00125.

[21] F. Le Roux, K.M. Wegner, M.F. Polz, Oysters and Vibrios as a Model for Disease Dynamics in Wild Animals, Trends Microbiol. 24 (2016) 568-580. doi:10.1016/j.tim.2016.03.006.

[22] B. Petton, M. Bruto, A. James, Y. Labreuche, M. Alunno-Bruscia, F. Le Roux, 
Crassostrea gigas mortality in France: The usual suspect, a herpes virus, may not be the killer in this polymicrobial opportunistic disease, Front. Microbiol. 6 (2015) 1-10. doi:10.3389/fmicb.2015.00686.

[23] M. Fuhrmann, B. Petton, V. Quillien, N. Faury, B. Morga, F. Pernet, Salinity influences disease-induced mortality of the oyster Crassostrea gigas and infectivity of the ostreid herpesvirus 1 (OsHV-1), Aquac. Environ. Interact. 8 (2016) 543-552. doi:10.3354/aei00197.

[24] M. Suquet, G. De Kermoysan, R.G. Araya, I. Queau, L. Lebrun, P. Le Souchu, C. Mingant, Anesthesia in Pacific oyster, Crassostrea gigas, Aquat. Living Resour. 22 (2009) 29-34. doi:10.1051/alr/2009006.

[25] E. Fleury, J. Normand, A. Lamoureux, J.-F. Bouget, C. Lupo, N. Cochennec-Laureau, S. Petton, B. Petton, Pouvreau Stephane, National monitoring network of mortality and growth rates of the sentinel oyster Crassostrea gigas, SEANOE. (2018). doi:10.17882/53007.

[26] P. Hick, O. Evans, R. Looi, C. English, R.J. Whittington, Stability of Ostreid herpesvirus-1 (OsHV-1) and assessment of disinfection of seawater and oyster tissues using a bioassay, Aquaculture. 450 (2016) 412-421. doi:10.1016/j.aquaculture.2015.08.025.

[27] J.F. Pepin, A. Riou, T. Renault, Rapid and sensitive detection of ostreid herpesvirus 1 in oyster samples by real-time PCR, J. Virol. Methods. 149 (2008) 269-276. doi:10.1016/j.jviromet.2008.01.022.

[28] S.C. Webb, A. Fidler, T. Renault, Primers for PCR-based detection of ostreid herpes virus1 (OsHV-1): Application in a survey of New Zealand molluscs, Aquaculture. 272 (2007) 
126-139. doi:10.1016/j.aquaculture.2007.07.224.

[29] A. Huvet, J.. Daniel, C. Quéré, S. Dubois, M. Prudence, A. Van Wormhoudt, D. Sellos, J.F. Samain, J. Moal, Tissue expression of two a-amylase genes in the Pacific oyster Crassostrea gigas. Effects of two different food rations, Aquaculture. 228 (2003) 321-333. doi:10.1016/S0044-8486(03)00323-5.

[30] A. Segarra, N. Faury, J. Pépin, T. Renault, Transcriptomic study of 39 ostreid herpesvirus 1 genes during an experimental infection, J. Invertebr. Pathol. 119 (2014) 5-11. doi:10.1016/j.jip.2014.03.002.

[31] K.J. Livak, T.D. Schmittgen, Analysis of relative gene expression data using real-time quantitative PCR and the 2- $\Delta \Delta \mathrm{CT}$ method, Methods. 25 (2001) 402-408. doi:10.1006/meth.2001.1262.

[32] R. Rasmussen, Quantification on the LightCycler, in: Rapid Cycle Real-Time PCR, Springer, Berlin, Heidelb., 2001.

[33] E.L. Kaplan, P. Meier, Nonparametric Estimation from Incomplete Observations, Am. Stat. Assoc. 53 (1958) 457-481. doi:10.2307/2281868.

[34] D.Y. Lin, L.J. Wei, Z. Ying, Checking the Cox model with cumulative sums of martingale-based residuals, Biometrika. 80 (1993) 557-572. doi:10.1093/biomet/80.3.557.

[35] A. Segarra, Etude des interactions hôte/virus chez l'huître creuse, Crassostrea gigas, et son virus Ostreid herpesvirus 1, PhD dissertation, Université de Bretagne Sud, 262pp, 2015.

[36] P.W. Hochachka, G.. Somero, Biochemical adaptation: mechanism and process in 
505

506

507

508

509

510

511

512

513

514

515

516

517

518

519

520

521

522

523

524

525

526

physiological evolution, Oxford Uni, 2002.

[37] T.J. Green, C. Montagnani, K. Benkendorff, N. Robinson, P. Speck, Ontogeny and water temperature influences the antiviral response of the Pacific oyster, Crassostrea gigas, Fish Shellfish Immunol. 36 (2014) 151-157. doi:10.1016/j.fsi.2013.10.026.

[38] Y.R. Lin, H.C. Hung, J.H. Leu, H.C. Wang, G.H. Kou, C.F. Lo, The Role of Aldehyde Dehydrogenase and Hsp70 in Suppression of White Spot Syndrome Virus Replication at High Temperature, J. Virol. 85 (2011) 3517-3525. doi:10.1128/JVI.01973-10.

[39] A. Lemire, D. Goudenège, T. Versigny, B. Petton, A. Calteau, Y. Labreuche, F. Le Roux, Populations, not clones, are the unit of vibrio pathogenesis in naturally infected oysters, ISME J. 9 (2015) 1523-1531. doi:10.1038/ismej.2014.233.

[40] C. Choi, D.H. Kingsley, Temperature-Dependent Persistence of Human Norovirus Within Oysters (Crassostrea virginica), Food Environ. Virol. 8 (2016) 141-147. doi:10.1007/s12560-016-9234-8.

[41] M.A. Jarvis, J.A. Nelson, Human cytomegalovirus persistence and latency in endothelial cells and macrophages, Curr. Opin. Microbiol. 5 (2002) 403-407. doi:https://doi.org/10.1016/S1369-5274(02)00334-X.

[42] F. Pernet, D. Tamayo, B. Petton, In fl uence of low temperatures on the survival of the Pacific oyster (Crassostrea gigas) infected with ostreid herpes virus type 1, Aquaculture. 445 (2015) 57-62. doi:10.1016/j.aquaculture.2015.04.010.

[43] L. Dégremont, P. Boudry, M. Ropert, J.F. Samain, E. Bédier, P. Soletchnik, Effects of age and environment on survival of summer mortality by two selected groups of the Pacific oyster Crassostrea gigas, Aquaculture. 299 (2010) 44-50. 
doi:10.1016/j.aquaculture.2009.12.009.

[44] T.J. Little, A.R. Kraaijeveld, Ecological and evolutionary implications of immunological priming in invertebrates, Trends Ecol. Evol. 19 (2004) 58-60. doi:10.1016/j.tree.2003.11.011.

[45] B. Milutinović, J. Kurtz, Immune memory in invertebrates, Semin. Immunol. 28 (2016) 328-342. doi:10.1016/j.smim.2016.05.004.

[46] T.J. Green, C. Montagnani, Poly I: C induces a protective antiviral immune response in the Pacific oyster (Crassostrea gigas) against subsequent challenge with Ostreid herpesvirus (OsHV-1 $\mu$ var), Fish Shellfish Immunol. 35 (2013) 382-388. doi:10.1016/j.fsi.2013.04.051.

[47] M.M. Rahman, C.M. Escobedo-bonilla, M. Corteel, J.J. Dantas-lima, Effect of high water temperature $\left(33{ }^{\circ} \mathrm{C}\right)$ on the clinical and virological outcome of experimental infections with white spot syndrome virus (WSSV) in specific pathogen-free (SPF) Litopenaeus vannamei, Aquaculture. 261 (2006) 842-849. doi:10.1016/j.aquaculture.2006.09.007.

Table 1. List of all treatment combinations used in experiments $1 \mathrm{~A}, 1 \mathrm{~B}$ and 2 in the laboratory. Abbreviations: SSW, synthetic seawater; A, acclimated; NA, non-acclimated.

\begin{tabular}{lccccc}
\hline Seawater & Injection & Injection & Replicate & Tank Acclimation Experiment \\
temperature & & & & \\
& temperature & & & \\
& & &
\end{tabular}




\begin{tabular}{|c|c|c|c|c|c|c|}
\hline $\begin{array}{l}\text { Seawater } \\
\text { temperature }\end{array}$ & Injection & $\begin{array}{l}\text { Injection } \\
\text { temperatu }\end{array}$ & Replicate & Tank & Acclimation & Experiment \\
\hline \multirow[t]{15}{*}{$21^{\circ} \mathrm{C}$} & SSW & $21^{\circ} \mathrm{C}$ & 1 & 1 & A & $1-2$ \\
\hline & & & 2 & 2 & A & $1-2$ \\
\hline & & $26^{\circ} \mathrm{C}$ & 1 & 3 & A & \\
\hline & & & 2 & 4 & A & 2 \\
\hline & & $29^{\circ} \mathrm{C}$ & 1 & 5 & $\mathrm{~A}$ & 2 \\
\hline & & & 2 & 6 & A & 2 \\
\hline & OsHV-1 & $21^{\circ} \mathrm{C}$ & 1 & 7 & A-NA & $1-2$ \\
\hline & & & 2 & & A-NA & $1-2$ \\
\hline & & & 3 & 9 & A-NA & $1-2$ \\
\hline & & $26^{\circ} \mathrm{C}$ & 1 & 10 & A & 2 \\
\hline & & & 2 & 11 & A & 2 \\
\hline & & & & 12 & A & 2 \\
\hline & & 29 & 1 & 13 & A & 2 \\
\hline & & & 2 & 14 & A & 2 \\
\hline & & & 3 & 15 & A & 2 \\
\hline \multirow[t]{5}{*}{$26^{\circ} \mathrm{C}$} & SSW & $21^{\circ} \mathrm{C}$ & 1 & 16 & A & 1 \\
\hline & & & 2 & 17 & A & 1 \\
\hline & OsHV-1 & $21^{\circ} \mathrm{C}$ & 1 & 18 & A-NA & 1 \\
\hline & & & 2 & 19 & A-NA & 1 \\
\hline & & & 3 & 20 & A-NA & 1 \\
\hline $29^{\circ} \mathrm{C}$ & SSW & $21^{\circ} \mathrm{C}$ & 1 & 21 & A & 1 \\
\hline
\end{tabular}




\begin{tabular}{lllll}
\hline Seawater Injection & Injection & Replicate & Tank Acclimation & Experiment
\end{tabular}
temperature temperature

\begin{tabular}{llllll}
\hline & & 2 & 22 & A & 1 \\
\cline { 2 - 5 } OsHV-1 & $21^{\circ} \mathrm{C}$ & 1 & 23 & A-NA & 1 \\
& 2 & 24 & A-NA & 1 \\
& 3 & 25 & A-NA & 1 \\
\hline
\end{tabular}

545

546 
Fig. 1. Experimental design to investigate the effect of temperature on disease susceptibility of the Pacific oyster Crassostrea gigas and virulence of the Ostreid herpesvirus type 1. Abbreviations: OsHV-1, Ostreid herpesvirus type 1; SPF, specific-pathogen free oyster; SSW, synthetic seawater.

Fig. 2. (A) Survival of oysters (pathogen recipients) having cohabited with donors injected with OsHV- 1 at $21^{\circ} \mathrm{C}, 26^{\circ} \mathrm{C}$ and $29^{\circ} \mathrm{C}$ with or without prior acclimation. (B) Quantification of OsHV1 DNA in pathogen recipients as a function of temperature. Data of acclimated and nonacclimated oysters were averaged due to temperature $\times$ acclimation $\times$ time interaction not being significant. Inset represents the significant interaction of temperature $\times$ acclimation. Data were $\log (\mathrm{x}+1)$ transformed. (C and D) Viral gene expression expressed as a delta threshold cycle number $(\mathrm{Ct})$ of OsHV-1 open reading frames (ORFs) relative to $C$. gigas elongation factor in live acclimated pathogen recipients as a function of temperature. Inset represents the main effect of time averaged for the six tested ORFs. The gene expression analyses were conducted only at 24 hpc and 48 hpc. For all analyses, values are means \pm SE ( $n=3$ tanks), and different letters indicate significant differences. Only significant effects are represented.

Fig. 3. Survival of pathogen recipient after being transferred to a farming area where OsHV-1 occurred as a function of temperature during the first exposure to OsHV-1 in the laboratory.

Fig. 4. (A) Survival of oysters (pathogen recipients) having cohabited with donors injected with OsHV-1 incubated at $21^{\circ} \mathrm{C}, 26^{\circ} \mathrm{C}$ and $29^{\circ} \mathrm{C}$ for 5 hours. (B) Quantification of OsHV-1 DNA in 567 pathogen recipients as a function of incubation temperature of the viral suspension. Data of 568 recipients at $21^{\circ} \mathrm{C}, 26^{\circ} \mathrm{C}$ and $29^{\circ} \mathrm{C}$ were averaged because the interaction of temperature $\times$ time 569 was not significant (black line). Data were $\log (\mathrm{x}+1)$ transformed. (C) Viral gene expression 
570 expressed as a delta threshold cycle number $(\mathrm{Ct})$ of OsHV-1 open reading frames (ORFs) relative

571 to $C$. gigas elongation factor 1 in live acclimated recipients as a function of time. The gene

572 expression analyses were conducted only at $24 \mathrm{hpc}$ and $48 \mathrm{hpc}$. For all analyses, values are means

$573 \pm \mathrm{SE}(\mathrm{n}=3$ tanks), and different letters indicate significant differences. Only significant effects are 574 represented.

575 
Fig. 1.

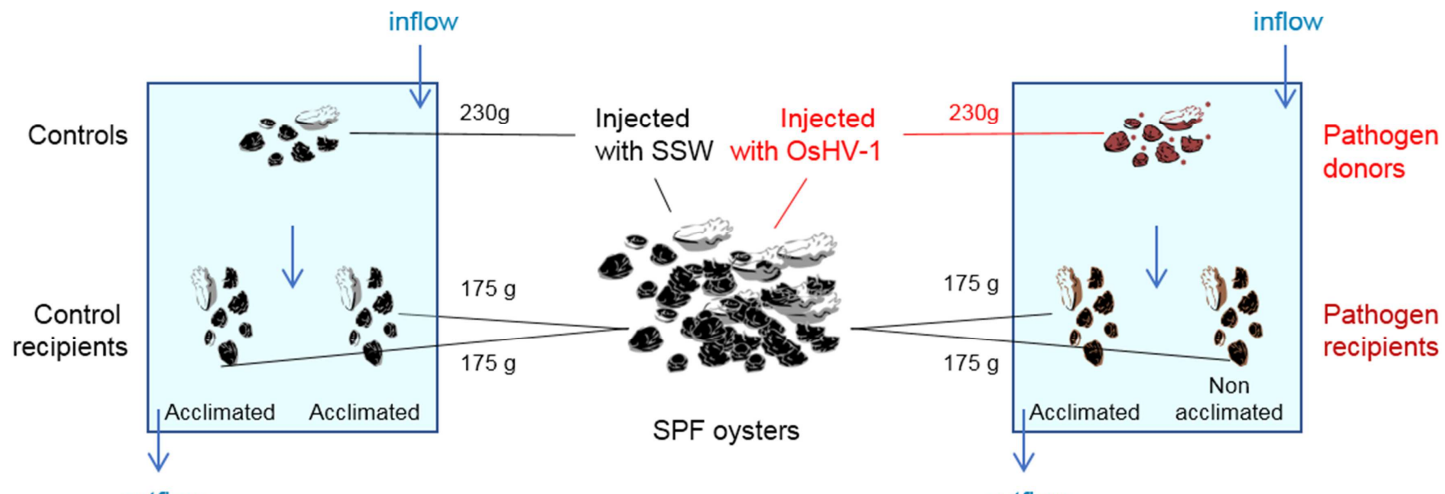

outflow

$\times 3$ temperatures $\times 2$ replicate tanks

outflow

$\times 3$ temperatures $\times 3$ replicate tanks

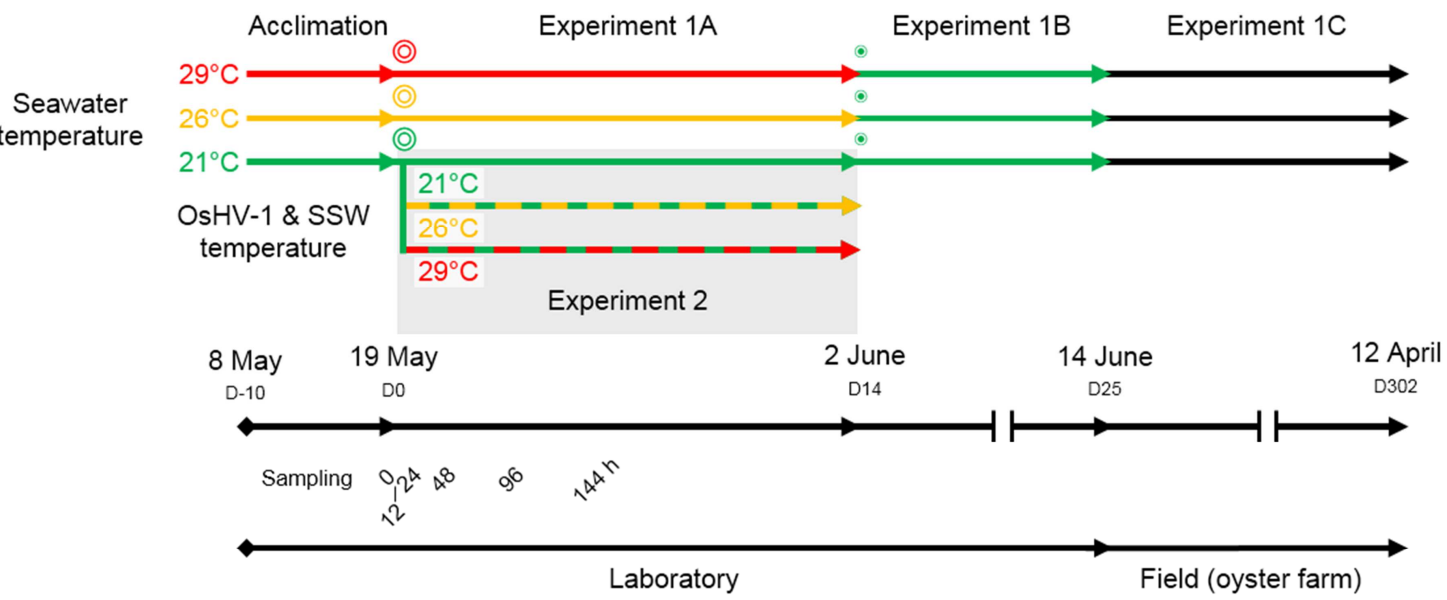

(?) Addition of non-acclimated recipients

- Addition of new SPF recipients 
A

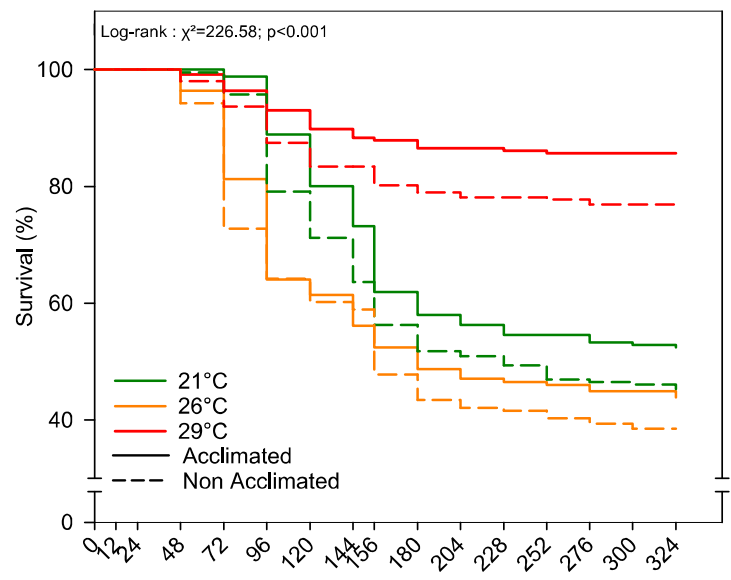

Time (hpc)

C

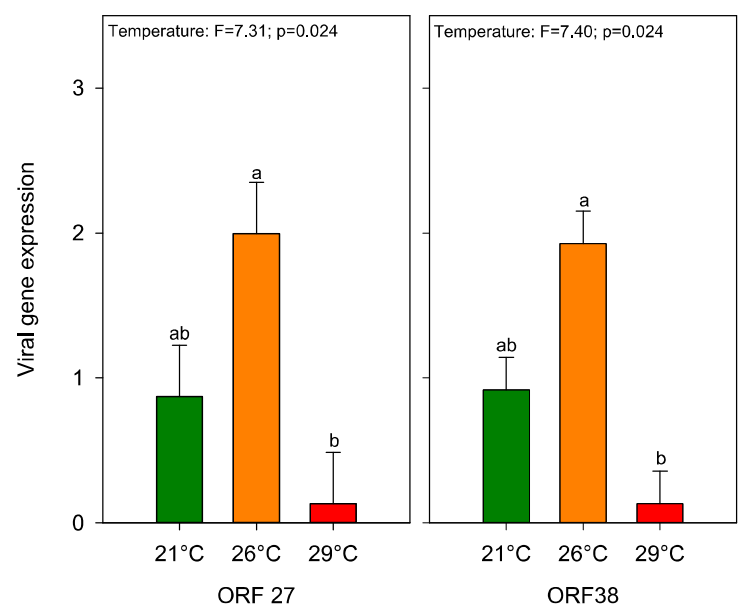

B
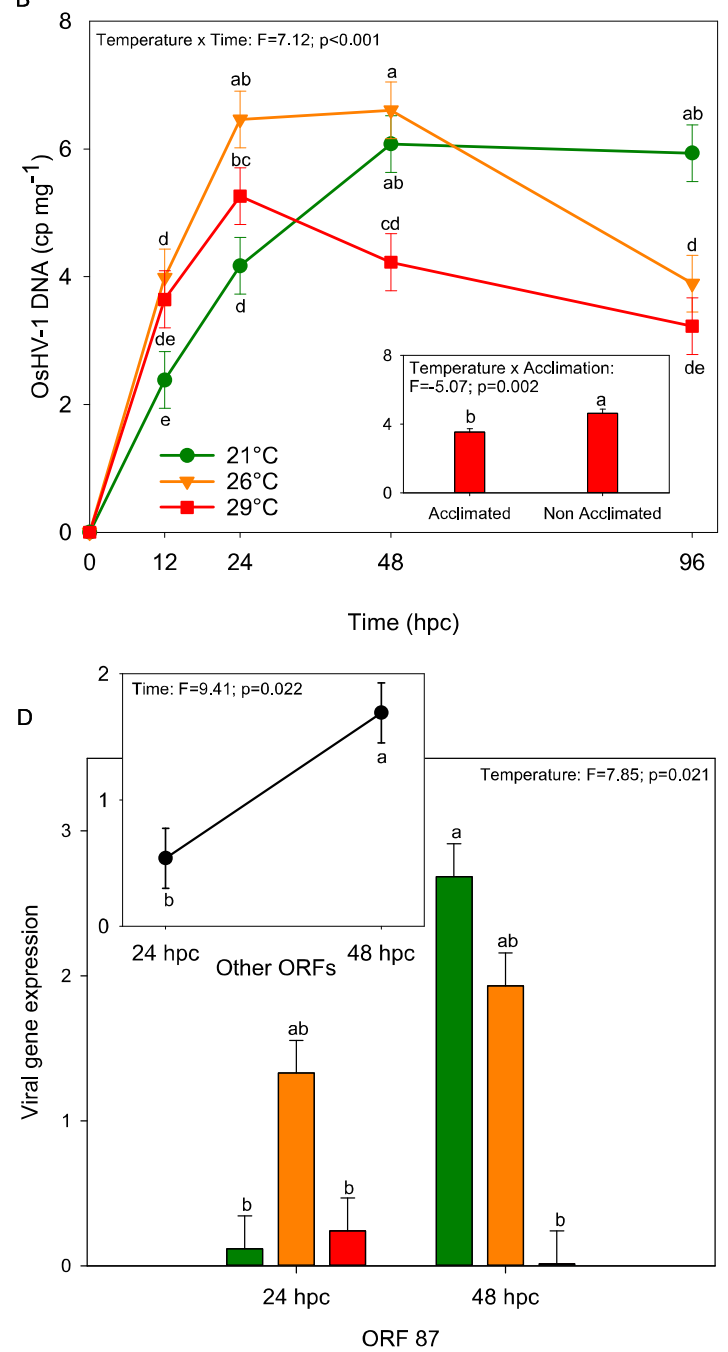
Fig. 3.

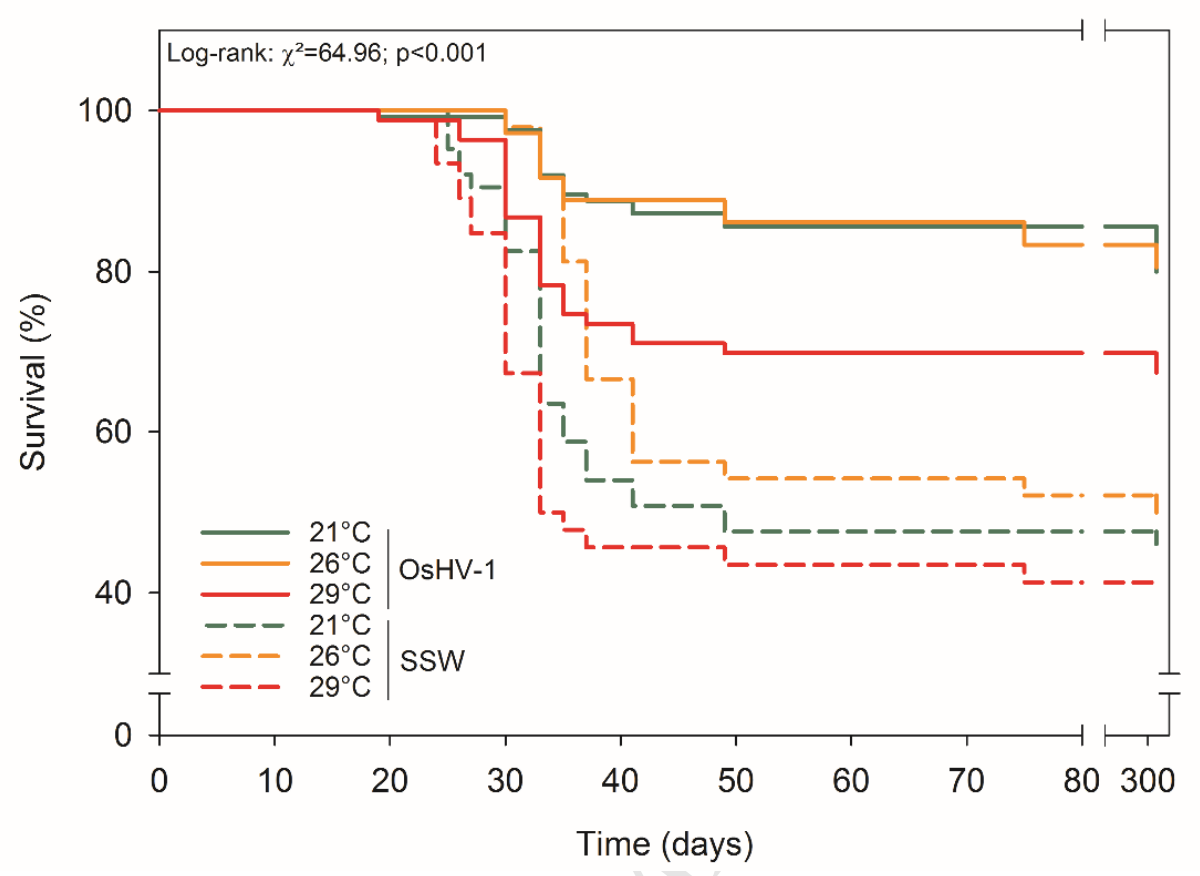


Fig. 4.
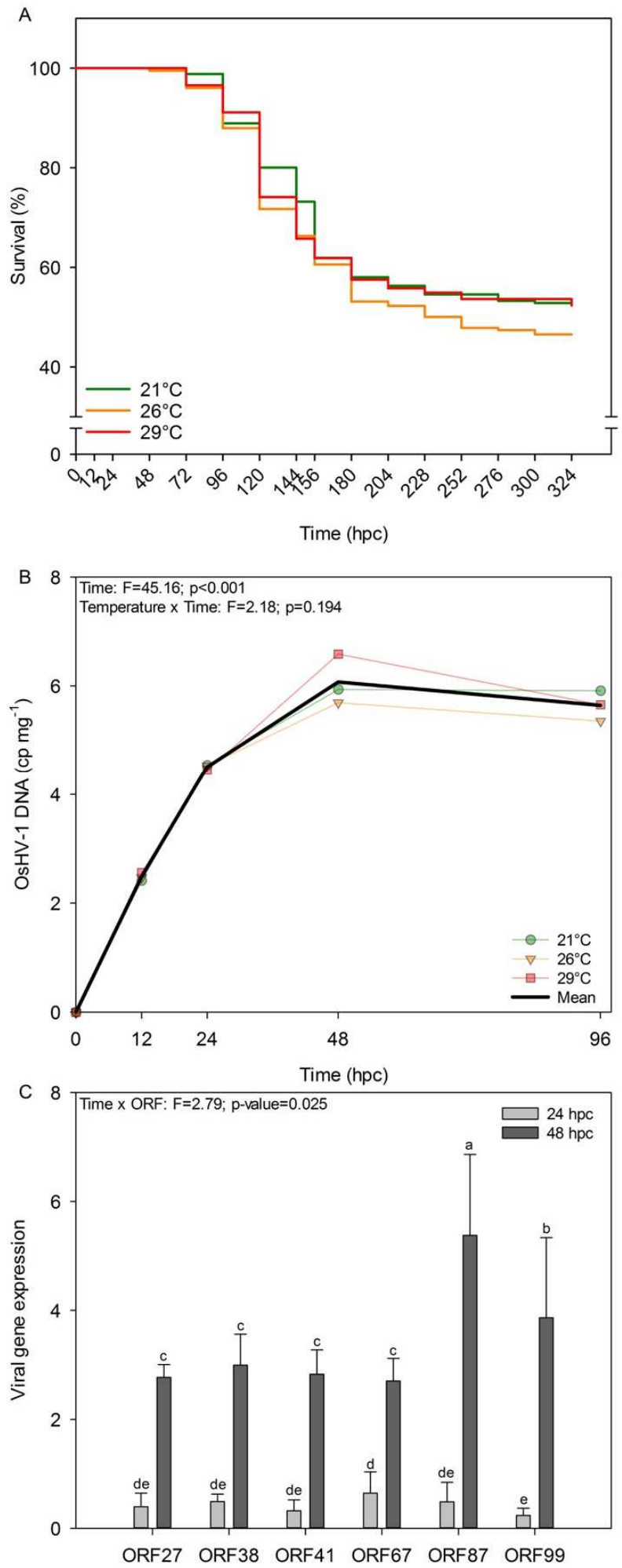